\title{
Estimation of energy-saving potential and indoor thermal comfort by the central control of the heating curve in old apartment buildings
}

\author{
Hatef Hajian ${ }^{1 *}$, Kaiser Ahmed ${ }^{1,2}$, and Jarek Kurnitski ${ }^{1,3}$ \\ ${ }^{1}$ Aalto University, Department of Civil Engineering, 02150 Espoo, Finland \\ ${ }^{2}$ Granlund Consulting Oy, 00701 Helsinki, Finland \\ ${ }^{3}$ Tallinn University of Technology, Smart City Centre of Excellence, 19086 Tallinn, Estonia
}

\begin{abstract}
In this research, an existing building calibrated simulation model from 1981 was built based on measured energy and indoor temperature data. The model was used to study the central control's energysaving potential. With parametric simulations, DHW circulation internal heat gain and ventilation airflow rate was determined as $85 \%$ and $0.291 / \mathrm{s} / \mathrm{m}^{2}$, respectively. DHW circulation heat loss has been found almost as high as DHW use. Dropping the heating curve from $70 / 40{ }^{\circ} \mathrm{C}$ to $65 / 35^{\circ} \mathrm{C}$ resulted in a saving of 0.6 $\mathrm{kWh} / \mathrm{m}^{2} \mathrm{a}(0.8 \%$ of space heating energy) on the cost of thermal comfort as yearly hours of the mean air temperature below $21{ }^{\circ} \mathrm{C}$ rose from $2.7 \%$ to $9.0 \%$. It was necessary to reduce the heating curve to $55 / 25^{\circ} \mathrm{C}$ in a hypothetical scenario with fully open thermostats, indicating heat redistribution from warmer to colder rooms, leading to higher heating energy. The findings indicate no energy saving potential due to compromising thermal comfort even by $5{ }^{\circ} \mathrm{C}$ heating curve reduction. It was revealed that the building average indoor temperature is not a factor to estimate energy-saving potential because of too low temperature in the coldest apartments.
\end{abstract}

\section{Introduction}

The energy use of buildings accounts for about $40 \%$ of the world's overall primary energy demand [1]. The residential building's contribution to the overall final energy usage in European countries is $25.3 \%$ [2]. In the European Union (EU) residential building stock, $79 \%$ of the overall energy is used for space and hot water heating [3, 4]. Hence, heating energy in residential buildings plays a vital role in the EU 2030 climate and energy framework targets, according to which the energy efficiency needs to be improved by at least $32.5 \%$ [5].

Across the EU, District Heating (DH) networks are mostly utilised in Scandinavian and Eastern European countries [6]. Regarding the Heat Roadmap Europe [7], DH will serve a major task in the future deployment of Renewable Energy Sources (RES) in energy system obtained by lowering the DH system's temperature. Benakopoulos et al. (2019) [8] explained the existing Medium Temperature DH (MTDH) or the DH system third generation, typically operates with 85 and $45^{\circ} \mathrm{C}$ as supply and return temperatures, respectively, in the building substation primary side. In the LowTemperature DH (LTDH) or the comer DH system fourth generation, the DH supply and return temperatures are considered5 and $25{ }^{\circ} \mathrm{C}$, respectively [8]. In general, the DH operator uses a weathercompensated DH supply temperature [9].

The Space Heating ( $\mathrm{SH}$ ) systems in existing buildings are designed for extremely low ambient temperatures and have enough capacity to provide sufficient thermal comfort at lower supply temperatures [10], because solar and internal heat gains are not taken into account in sizing [8]. Therefore, it can be feasible to run the existing buildings $\mathrm{SH}$ networks with lower supply temperature during a year; however, the $\mathrm{SH}$ systems control may require enhancement to maintain the low return temperature and detecting and resolving the potential errors [11]. In terms of underheated or overheated apartments, thermal comfort significantly influences occupants' health and mood since individuals spend almost $90 \%$ of their time living indoors [12]. Moreover, the absence of a balanced heating system, elevated Heating Curve (HC), and fully open or defective thermostats may lead to overheated indoor air temperature. The radiators' heat output can be reduced by lowering the HC supply and return temperature [8]. Reducing HC supply and return temperature will provide direct energy-saving and co-benefits in DH production and distribution, leading to better generation efficiency and less pipe network heat losses. However, it is a question of how much the heating curve can be lowered because heat gains and losses may vary widely in different dwellings under different circumstances. It is important that energy-saving will not compromise thermal comfort. We hypothesise that the lowest possible $\mathrm{HC}$ is different if all radiators are controlled by thermostats with a correct setpoint of about $21^{\circ} \mathrm{C}$ or if some thermostats are fully open, as can be the situation in practice [13-15]. In the latter case, the heat will be redistributed from overheated rooms to other apartments because internal walls and slabs are not insulated, which could allow further reduction of the heating curve.

The purpose of this study was to estimate the energysaving potential of a building without compromising thermal comfort by regulating the central control of the $\mathrm{DH}$ substation based on the indoor temperatures. The

\footnotetext{
* Corresponding author : hatef.hajian@aalto.fi
} 
analysis investigated two typical 4-story Finnish blocks of apartments constructed in 1981 according to available onsite measured data of heating and indoor air temperatures. The model calibration and energy simulations were conducted with the IDA Indoor Climate and Energy (IDA ICE) simulation tool. The amount of DHW and its circulation heat loss was determined based on the DH usage in the warmest months (Jul. and Aug.), which is the aggregation of DHW and DHW circulation heat loss. Subsequently, the amount of DHW usage was calculated, and its proportion (1/per. /day) to DCW usage in Jul. and Aug. was determined. The ratio was utilised to find the DHW usage in other months. Finally, the model was calibrated against the measured data. The energy-saving potential and thermal comfort were investigated between three heat curves of $61 / 31{ }^{\circ} \mathrm{C}, 65 / 35{ }^{\circ} \mathrm{C}$ and $70 / 40{ }^{\circ} \mathrm{C}$. Thermal comfort was analysed based on the mean air temperature in apartments and counting the hours when the air temperature was below $21^{\circ} \mathrm{C}$ and operative temperature below $20^{\circ} \mathrm{C}$. Additionally, the simulation model was applied for an overheated apartment building to determine the central control's energy-saving potential. Analyses were limited to the weather compensated HC; however, the developed calibrated model is suitable for applying dynamic control planned in the next phase of the study.

\section{Methods}

\subsection{Building model and technical description}

\subsubsection{The building model}

In this study, two 4-story blocks of concert apartment buildings (A and B) in Helsinki, Finland, constructed in 1981, was used (see Fig.1). The buildings consisted of 60 zones identified as either one apartment, staircase, or common room. The heated area was $4052.5 \mathrm{~m}^{2}$, where inhabited 104 occupants. The heat transmittance coefficient (U-value) of external wall, roof, external floor, and glazing were $0.34,0.29,0.29$ and $2.1 \mathrm{~W} /\left(\mathrm{m}^{2}\right.$ $\mathrm{K})$, respectively. The air temperature data of 23 apartments was measured. The building envelope features are represented in table 1.

Table 1. Building envelope features.

\begin{tabular}{lr}
\hline External walls in outdoor air, $\mathrm{m}^{2}$ & 2552.2 \\
Roof area, $\mathrm{m}^{2}$ & 1114.1 \\
Window area, $\mathrm{m}^{2}$ & 362.1 \\
External door area, $\mathrm{m}^{2}$ & 31.2 \\
\hline
\end{tabular}

Both building parts were modelled in Autodesk Revit 2018 (BIM) software [16]. Subsequently, the IFC file was extracted from Autodesk Revit and imported to IDA ICE Building Performance Simulation (BPS) software [17]. The simulation was carried out during the year 2018. A multiplier of 2 was utilised for middle floor zones to simplify the model, which means that the respective zones' characteristics were multiplied by 2 . Figure 2 shows the 3D model of the buildings in the IDA ICE application.

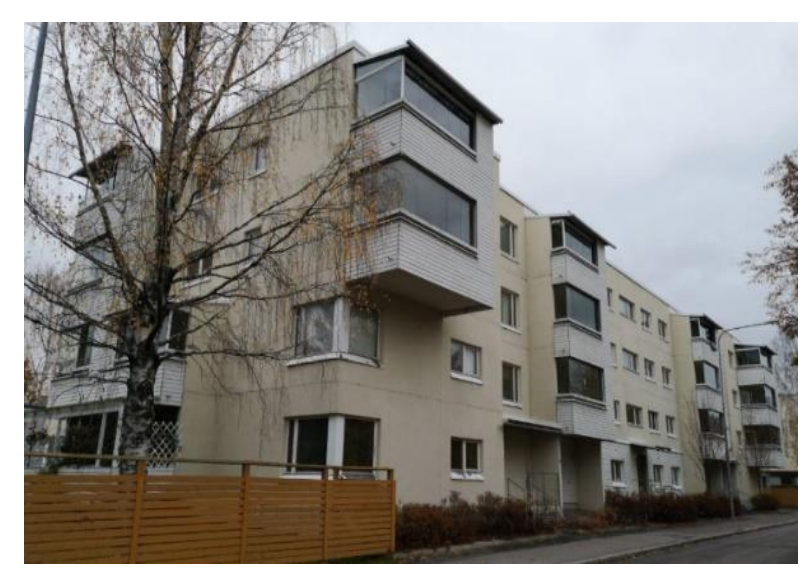

(a)

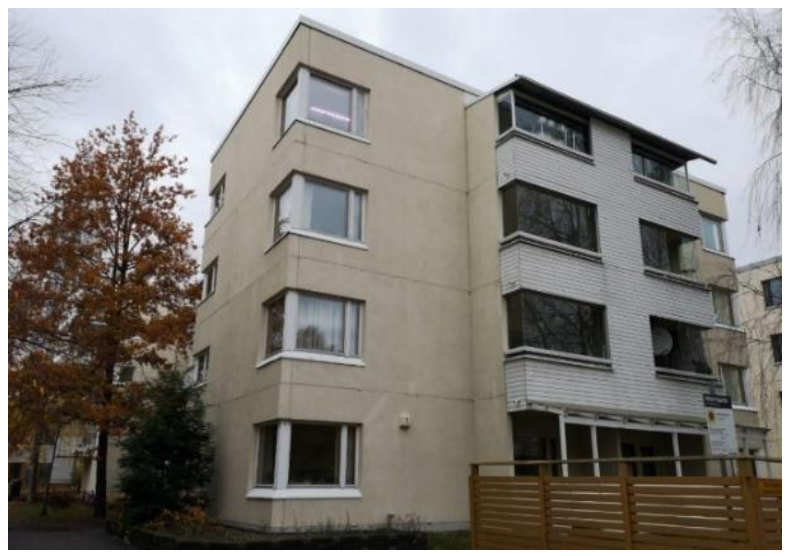

(b)

Figure 1. Measured cases view a) building A, b) building B.

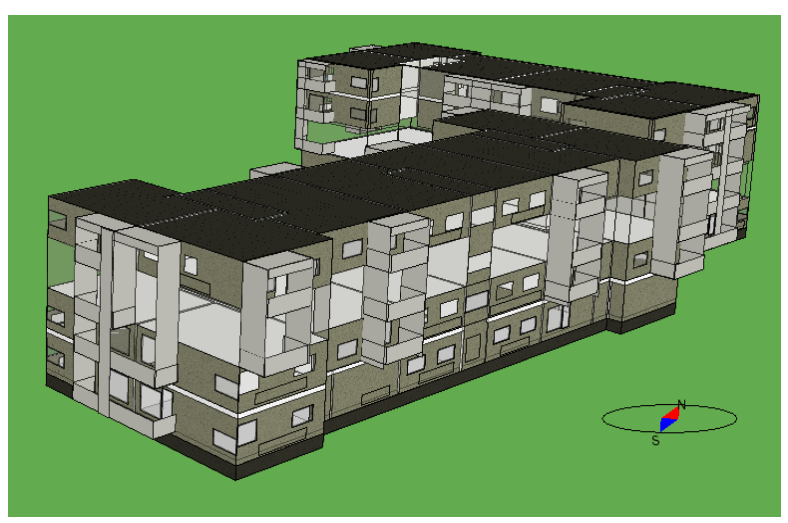

Figure 2. The 3D model of the apartment buildings in the IDA ICE simulation tool. To simplify the model, a multiplier of 2 was utilised for the middle floors.

\subsubsection{The building technical description}

There was a mechanical exhaust ventilation system along 3 and 2 fans located on the building A and B roof, respectively. Each fan's airflow rate was mentioned in the as-built drawings; however, the actual airflow rate was unknown and was identified in the model calibration phase to be $0.29 \mathrm{l} /\left(\mathrm{s} \mathrm{m}^{2}\right)$. In warm months (Apr. to Sep.), the window opening effect was taken into account by increasing the airflow rate to $0.45 \mathrm{l} /\left(\mathrm{s} \mathrm{m}^{2}\right)$. According to the building facility manager, the fan 
operation schedule on weekdays and weekends-holidays was used as shown in table 2.

Table 2. Fan operation schedule in weekdays and weekendsholidays.

\begin{tabular}{|l|c|c|}
\hline \multirow{2}{*}{ Time } & \multicolumn{2}{|c|}{ Fan power } \\
\cline { 2 - 3 } & $100 \%$ & $70 \%$ \\
\hline \multirow{3}{*}{ Weekdays } & $06: 00$ to $08: 00$ & $00: 00$ to $06: 00$ \\
\cline { 2 - 3 } & $16: 00$ to $19: 00$ & $08: 00$ to $16: 00$ \\
\cline { 3 - 3 } & $07: 00$ to $10: 00$ & $00: 00$ to $07: 00$ \\
\hline \multirow{2}{*}{$\begin{array}{l}\text { Weekends and } \\
\text { Holidays }\end{array}$} & $17: 00$ to $21: 00$ & $10: 00$ to $17: 00$ \\
\cline { 2 - 3 } & & $21: 00$ to $24: 00$ \\
\hline
\end{tabular}

Water radiators and proportional thermostats with the dead band of $2 \mathrm{~K}$ were used to model the SH system. The radiator was type 11 with $1018 \mathrm{~W} / \mathrm{m}$ heat output at $70 / 40 / 21 \mathrm{C}$. The height of all radiators was $600 \mathrm{~mm}$. Oversizing of $10 \%$ was applied in a common sizing procedure without no heat gains and at the designed outdoor temperature of $-26{ }^{\circ} \mathrm{C}$. The length of each radiator was selected so that precisely $10 \%$ of oversizing was provided.

The building leakage rate was identified in the model calibration to be about $4 \mathrm{~m}^{3} /\left(\mathrm{h} . \mathrm{m}^{2}\right.$ ext. surf.) at $50 \mathrm{~Pa}$ pressure difference. Detailed infiltration airflow simulation was conducted with local weather station wind speed and semi-exposed pressure coefficients of the Air Infiltration and Ventilation Centre (AIVC). Ahmed et al. described the daily internal gain profiles [18]. Therefore, the average occupancy rate, usage factor and lighting usage factor were considered as 0.6 , 0.6 and 0.1 , respectively (see fig. 3 ).

According to the national building code of Finland [19], the appliance power was considered as $4 \mathrm{~W} / \mathrm{m}^{2}$. To compensate for higher measured electricity use, the appliance power was increased in the model calibration

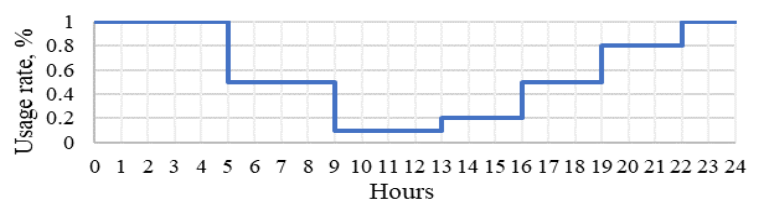

(a)

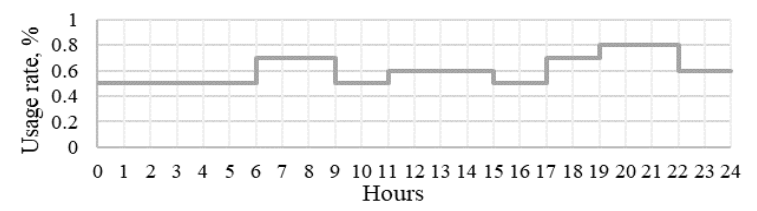

(b)

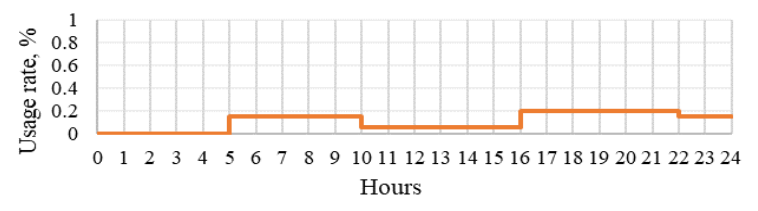

(c)

Figure 3. The internal heat gain profile a) Occupancy, b) Appliances, c) Lighting. phase to $4.4 \mathrm{~W} / \mathrm{m}^{2}$, and the additional appliance profile was utilised as $1 \mathrm{~W} / \mathrm{m}^{2}$ in cold months (Jan to Mar. and Oct. to Dec.), shown in figure 4.

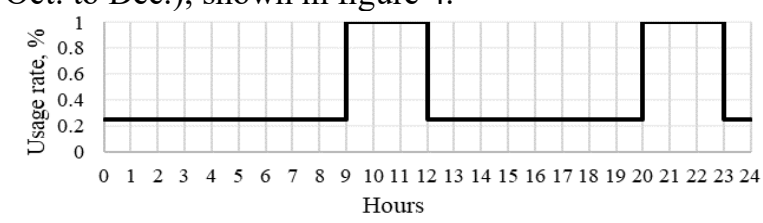

Figure 4. The additional appliance profile (Jan. to Mar. and Oct. to Dec.)

\subsubsection{The onsite measured data}

Measured consumption data consisted of total DH, total electricity energy use, and DCW consumption are shown in table 3 . The total electricity included the amount of electricity energy which was consumed in facilities and apartments.

Table 3. The measured DH, electricity and DCW usages.

\begin{tabular}{|l|c|c|c|c|c|}
\hline \multirow{2}{*}{ Month } & \multirow{2}{*}{$\begin{array}{c}\mathrm{DH}, \\
\mathrm{kWh} / \mathrm{m}^{2}\end{array}$} & \multicolumn{3}{|c|}{ Electricity, $\mathrm{kWh} / \mathrm{m}^{2}$} & \multirow{2}{*}{$\begin{array}{c}\text { DCW, } \\
\text { 1/per./day }\end{array}$} \\
\cline { 3 - 5 } & & Facilities & Apartments & Total & \\
\hline Jan. & 16.99 & 0.80 & 2.67 & 3.47 & 166.4 \\
\hline Feb. & 18.28 & 0.69 & 2.26 & 2.96 & 159.8 \\
\hline Mar. & 18.18 & 0.84 & 2.36 & 3.20 & 150.5 \\
\hline Apr. & 11.68 & 0.73 & 2.09 & 2.82 & 189.0 \\
\hline May & 6.66 & 0.73 & 2.04 & 2.77 & 169.5 \\
\hline Jun. & 5.22 & 0.69 & 2.28 & 2.98 & 169.5 \\
\hline Jul. & 4.67 & 0.64 & 2.13 & 2.77 & 163.4 \\
\hline Aug. & 4.63 & 0.69 & 2.37 & 3.06 & 160.9 \\
\hline Sep. & 6.37 & 0.69 & 2.08 & 2.78 & 178.0 \\
\hline Oct. & 10.64 & 0.74 & 2.38 & 3.11 & 161.8 \\
\hline Nov. & 13.48 & 0.79 & 2.33 & 3.12 & 167.6 \\
\hline Dec. & 17.85 & 0.76 & 2.54 & 3.30 & 173.9 \\
\hline Total/Avg. & $\mathbf{1 3 4 . 7 / -}$ & $\mathbf{8 . 8} / \mathbf{-}$ & $\mathbf{2 7 . 5 / -}$ & $\mathbf{3 6 . 3} / \mathbf{-}$ & $-/ 167.5$ \\
\hline
\end{tabular}

\subsubsection{DHW usage calculation method}

Since DH, DCW and electricity consumption were available onsite measured data, the DHW usage was calculated as the DCW consumption ratio. In the warmest months (July and August), the only DH energy use is DHW and DHW circulation heat losses when there is no $\mathrm{SH}$ energy consumption. Considering early morning hours (02:00 to 04:00) while there is no DHW consumption, the DH use was assigned to the DHW circulation heat losses. The DHW circulation heat losses refer to pipe losses and the small towel drier radiators' heat output in the DHW loop in bathrooms.

In this building, the towel driers are fully open for the whole year. Therefore, the amount of DHW circulation heat loss can be assumed constant. The DHW usage amount was calculated by subtracting the DHW circulation heat loss amount from the DH usage in warm months. Knowing the DHW energy, the volume of DHW was calculated from Eq. 1.

Where:

$$
\mathrm{E}=\mathrm{m} * \mathrm{C}_{\mathrm{p}} * \frac{\Delta \mathrm{T}}{3600}
$$

$\mathrm{E}$ : energy, $\mathrm{kWh}$ 
$\mathrm{m}$ : the mass of water, 1

$\mathrm{C}_{\mathrm{p}}$ : specific heat of water, $\mathrm{kJ} / \mathrm{kg}{ }^{\circ} \mathrm{C}$

$\Delta \mathrm{T}$ : temperature difference, ${ }^{\circ} \mathrm{C}$

The ratio of DHW to DCW usage in warm months were determined, and the average ratio was considered for calculating the DHW usage in other months.

For comparison, a tabulated standard use value of Finnish building code [20] of $35 \mathrm{kWh} / \mathrm{m}^{2}$ was used as uncalibrated DHW. These were calculated with default values of [19] which do not include towel driers to include distribution losses.

\subsubsection{DHW consumption profile}

The DHW usage profile was implemented according to Ahmed et al. extensive DHW consumption in Finnish apartment building studies to simulate DHW fluctuations in a realistic fashion $[18,21]$.

\subsection{Model validation}

Index of agreement (d, Eq.2) and Coefficient of Variation of the Root Mean Square Error (CV(RMSE), Eq. 2) were used to assess the model performance. The index of agreement $d$ is often used to calculate the models' accuracy relative to the simulated results [22, 23]. The variation of $d$ is anywhere between 0 and 1 , with higher values indicating a good fit between the measured and simulated data.

$$
d=1-\frac{\sum_{i=1}^{n}\left(M_{i}-S_{i}\right)^{2}}{\sum_{i=1}^{n}\left(\mid S_{i}-\overline{\left.M|+| M_{l}-\bar{M} \mid\right)^{2}}\right.}
$$

Where:

$\mathrm{M}_{\mathrm{i}}$ is the measured value,

$\mathrm{S}_{\mathrm{i}}$ is the simulated value, and

$\bar{M}$ is the annual average measured value

Eq. 3 defines the $\mathrm{CV}(\mathrm{RMSE})$. According to ASHRAE Guideline 14 [24], if the calculated CV(RMSE) value was less than $15 \%$, the model is considered calibrated.

$$
\mathrm{CV}(\mathrm{RMSE})=\frac{\sqrt{\sum_{\mathrm{i}=1}^{\mathrm{n}}\left(\mathrm{M}_{\mathrm{i}}-\mathrm{S}_{\mathrm{i}}\right)^{2} / \mathrm{n}}}{\overline{\mathrm{M}}}
$$

Where:

$\mathrm{M}_{\mathrm{i}}$ is the measured value,

$\mathrm{S}_{\mathrm{i}}$ is the simulated value, and

$\overline{\mathrm{M}}$ is the annual average measured value

To ensure model validation, the Sensitivity Analysis (SA) was performed. Building energy analysis employed SA as a powerful method in energy simulation and experimental research. SA techniques used in building analysis can be categorised into local and global [25]. Wei Tian explains that local SA focuses on the impact of unknown inputs around a point, whereas global SA is involved with the effects of unknown inputs over the entire input space [25]. The building energy analysis field has employed the local SA [25] broadly.

\section{Results and analysis}

\subsection{Model calibration}

Measured DH data showed that the average monthly amount of the DHW circulation heat losses in July and August was 9.7 MWh, estimated as described in section 2.1.4. Table 4 shows the amount of energy consumption in warm months, consisting of DHW and the DHW circulation heat losses. Consequently, the DHW energy consumption was calculated by subtracting the DHW circulation heat losses from DH energy consumption.

Table 4. The DHW circulation heat losses and DHW energy in Jul. and Aug.

\begin{tabular}{lcc}
\hline \multicolumn{1}{c}{ Energy } & July & August \\
\hline DH (DHW + Circulation heat loss), MWh & 18.7 & 18.5 \\
Circulation loss, MWh & 9.0 & 9.0 \\
DHW energy, MWh & 9.7 & 9.5 \\
\hline
\end{tabular}

Knowing the DHW energy usage, the DHW volume consumption was determined by utilising Eq.1. Subsequently, the DHW usage in July and August was computed as $51.3 \mathrm{l} /$ (per./day). Compared to the average DCW usage in the same period (162.1 1/per./day), the average proportion of DHW to DCW was obtained $31.6 \%$, which was applied to calculate the DHW usage in other months. Table 5 illustrates the monthly DCW and DHW usage rate in 1/per./day.

Table 5. Monthly DH, DHW, DHW circulation heat loss energy, DCW and DHW usage.

\begin{tabular}{|l|c|c|c|c|}
\hline Month & $\begin{array}{c}\mathrm{DHW}, \\
\mathrm{kWh} / \mathrm{m}^{2}\end{array}$ & $\begin{array}{c}\text { DHW } \\
\text { circulation heat } \\
\text { loss, } \mathrm{kWh} / \mathrm{m}^{2}\end{array}$ & $\begin{array}{c}\text { DCW, } \\
\text { Lper./day }\end{array}$ & $\begin{array}{c}\text { DHW, } \\
\text { L/per./day }\end{array}$ \\
\hline Jan. & 2.5 & 2.3 & 166.4 & 52.7 \\
\hline Feb. & 2.2 & 2.0 & 159.8 & 50.6 \\
\hline Mar. & 2.3 & 2.3 & 150.5 & 47.6 \\
\hline Apr. & 2.8 & 2.2 & 189.0 & 59.8 \\
\hline May & 2.6 & 2.3 & 169.5 & 53.7 \\
\hline Jun. & 2.5 & 2.2 & 169.5 & 53.7 \\
\hline Jul. & 2.5 & 2.3 & 163.4 & 51.7 \\
\hline Aug. & 2.4 & 2.3 & 160.9 & 51.0 \\
\hline Sep. & 2.6 & 2.2 & 178.0 & 56.3 \\
\hline Oct. & 2.5 & 2.3 & 161.8 & 51.2 \\
\hline Nov. & 2.5 & 2.2 & 167.6 & 53.0 \\
\hline Dec. & 2.6 & 2.3 & 173.9 & 55.1 \\
\hline Total/Avg. & $\mathbf{2 9 . 9 / -}$ & $\mathbf{2 6 . 5} /-$ & $-/ \mathbf{1 6 7 . 5}$ & $-/ \mathbf{5 3 . 0}$ \\
\hline
\end{tabular}

Parametric simulations were conducted to identify correct input data parameters with the highest uncertainty. This comprised ventilation airflow rate, household appliances electricity use, heat gain ratio of DHW circulation and building leakage rate. Building envelope data was not changed in the calibration.

To identify the airflow rate and DHW circulation heat gain to rooms, the simulated annual space heating was calculated separately in different average airflow rates as $0.26,0.29$ and $0.32 \mathrm{l} / \mathrm{s} / \mathrm{m}^{2}$, while the DHW circulation heat gain to apartments was changed from $75 \%, 80 \%$ and $85 \%$. The results are shown in table 6 . The $\mathrm{d}$ values are very close, but the smallest CV(RMSE) concerning the minimum absolute deviation (0.18) was obtained as $8.94 \%$. As a result, the best combination of airflow rate and DHW circulation heat loss was 0.29 $1 / \mathrm{s} / \mathrm{m}^{2}$ and $85 \%$, respectively.

Figure 5 illustrates the SH dependency on the DHW circulation heat gain to zones changed from $75 \%$ to $85 \%$ at different airflow rates of $0.26,0.29$ and $0.32 \mathrm{1} / \mathrm{s} / \mathrm{m}^{2}$. 
Table 6. Identification of ventilation airflow rates and DHW circulation heat gain to rooms.

\begin{tabular}{|c|c|c|c|c|c|c|c|c|}
\hline \multicolumn{2}{|c|}{$\begin{array}{l}\text { Average airflow rate, } \\
11 / \mathrm{s} / \mathrm{m}^{2}\end{array}$} & \multirow{2}{*}{ 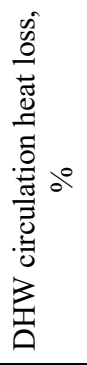 } & \multirow{2}{*}{ 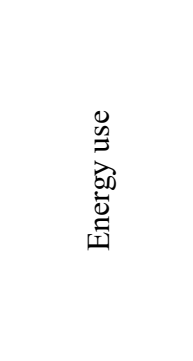 } & \multirow{2}{*}{ 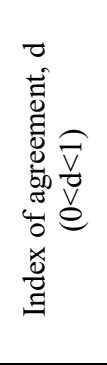 } & \multirow{2}{*}{ 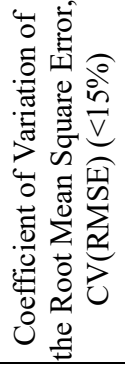 } & \multirow{2}{*}{ 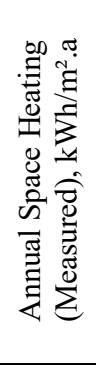 } & \multirow{2}{*}{ 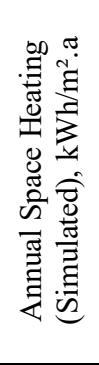 } & \multirow{2}{*}{$\begin{array}{l}.00 \\
.00 \\
.00 \\
0 \\
0 \\
0 \\
0 \\
0 \\
0 \\
0 \\
0\end{array}$} \\
\hline $\begin{array}{l}\text { Warm } \\
\text { months } \\
\text { (Mar. - } \\
\text { Oct.) }\end{array}$ & $\begin{array}{c}\text { Cold } \\
\text { months } \\
\text { (Nov. - } \\
\text { Feb.) }\end{array}$ & & & & & & & \\
\hline \multirow{3}{*}{0.41} & \multirow{3}{*}{0.26} & 75 & \multirow{3}{*}{ Space Heating } & 0.9976 & $8.32 \%$ & 78.24 & 76.12 & 2.12 \\
\hline & & 80 & & 0.9975 & $8.47 \%$ & 78.24 & 75.31 & 2.93 \\
\hline & & 85 & & 0.9973 & $8.81 \%$ & 78.24 & 74.5 & 3.74 \\
\hline \multirow{3}{*}{0.45} & \multirow{3}{*}{0.29} & 75 & \multirow{3}{*}{ Space Heating } & 0.9967 & $9.96 \%$ & 78.24 & 79.64 & 1.4 \\
\hline & & 80 & & 0.9971 & $9.37 \%$ & 78.24 & 78.83 & 0.59 \\
\hline & & 85 & & 0.9973 & $8.94 \%$ & 78.24 & 78.06 & 0.18 \\
\hline \multirow{3}{*}{0.49} & \multirow{3}{*}{0.32} & 75 & \multirow{3}{*}{ Space Heating } & 0.9938 & $13.96 \%$ & 78.24 & 83.21 & 4.97 \\
\hline & & 80 & & 0.9946 & $13.01 \%$ & 78.24 & 82.4 & 4.16 \\
\hline & & 85 & & 0.9953 & $12.12 \%$ & 78.24 & 81.59 & 3.34 \\
\hline
\end{tabular}

Results show good utilisation of circulation heat gain and are sensitive to the airflow rate as there is no heat recovery.

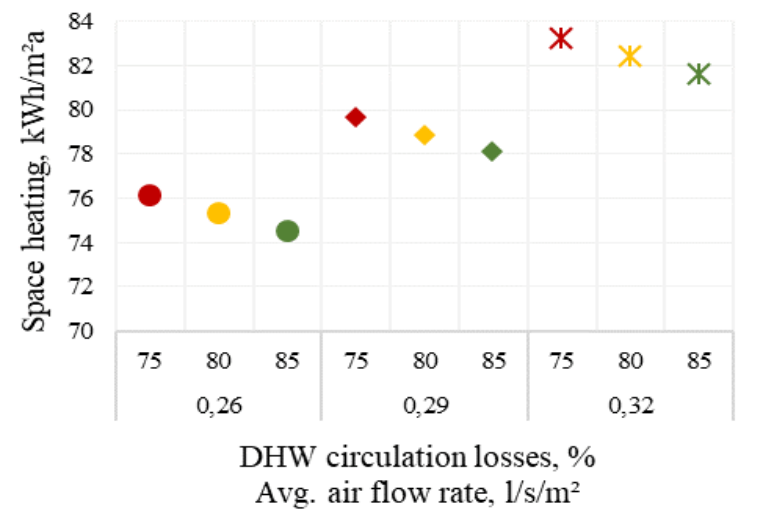

Figure 5. Sensitivity analysis for average airflow rate and DHW circulation heat gain.
Monthly measured, uncalibrated and calibrated data on SH, DHW and total electricity energy is shown in table 7. The DHW is considered as the summation of DHW and DHW circulation heat loss. The uncalibrated results were corrected during the model calibration process. The calibrated $\mathrm{SH}$ energy values while thermostats are fully open or broken ( $\mathrm{HC} 55 / 25{ }^{\circ} \mathrm{C}$, setpoint temp. $25^{\circ} \mathrm{C}$ ) are analysed in section 3.4.

Measured, uncalibrated and calibrated energy balance breakdown on annual bases is compared in table 8. The total DHW value in table 7 is split into DHW and DHW circulation heat loss. As discussed in section 2.1.4, uncalibrated DHW values correspond to the building code defaults. The measured electricity data consisted of the tenant and facility electricity that was simulated in IDA ICE in more detailed categories as fans and pumps, appliances and lighting.

Table 7. Measured, uncalibrated and calibrated energy usages.

\begin{tabular}{|c|c|c|c|c|c|c|c|c|c|c|}
\hline \multirow[b]{2}{*}{ Month } & \multicolumn{4}{|c|}{$\mathrm{SH}, \mathrm{kWh} / \mathrm{m}^{2}$} & \multicolumn{3}{|c|}{$\mathrm{DHW}, \mathrm{kWh} / \mathrm{m}^{2}$} & \multicolumn{3}{|c|}{ Total Electricity, $\mathrm{kWh} / \mathrm{m}^{2}$} \\
\hline & Measured & Uncalibrated & Calibrated & $\begin{array}{c}\mathrm{HC} 55 / 25^{\circ} \mathrm{C}, \\
\text { setpoint } 25^{\circ} \mathrm{C} \\
\text { (calibrated) }\end{array}$ & Measured & Uncalibrated & Calibrated & Measured & Uncalibrated & Calibrated \\
\hline Jan. & 12.21 & 15.52 & 13.30 & 13.16 & 4.77 & 3.95 & 4.75 & 3.47 & 2.77 & 3.15 \\
\hline Feb. & 14.06 & 16.96 & 14.87 & 15.06 & 4.22 & 3.57 & 4.29 & 2.96 & 2.50 & 2.88 \\
\hline Mar. & 13.65 & 14.06 & 14.00 & 14.33 & 4.53 & 3.95 & 4.75 & 3.20 & 2.77 & 3.25 \\
\hline Apr. & 6.73 & 5.11 & 6.76 & 7.92 & 4.95 & 3.83 & 4.60 & 2.82 & 2.68 & 2.94 \\
\hline May & 1.83 & 0.66 & 0.93 & 1.50 & 4.82 & 3.95 & 4.75 & 2.77 & 2.77 & 3.03 \\
\hline Jun. & 0.50 & 0.00 & 0.00 & 0.44 & 4.67 & 3.83 & 4.60 & 2.98 & 2.68 & 2.93 \\
\hline Jul. & 0.00 & 0.00 & 0.00 & 0.13 & 4.73 & 3.95 & 4.75 & 2.77 & 2.77 & 3.03 \\
\hline Aug. & 0.00 & 0.00 & 0.00 & 0.08 & 4.69 & 3.95 & 4.75 & 3.06 & 2.77 & 3.03 \\
\hline Sep. & 1.54 & 0.19 & 0.67 & 1.71 & 4.79 & 3.83 & 4.60 & 2.78 & 2.68 & 2.94 \\
\hline Oct. & 5.91 & 5.35 & 6.01 & 6.68 & 4.70 & 3.95 & 4.75 & 3.11 & 2.77 & 3.30 \\
\hline Nov. & 8.84 & 10.26 & 8.48 & 9.01 & 4.64 & 3.83 & 4.60 & 3.12 & 2.68 & 3.09 \\
\hline Dec. & 12.96 & 15.25 & 13.03 & 12.91 & 4.89 & 3.95 & 4.75 & 3.30 & 2.77 & 3.19 \\
\hline Total & 78.2 & 83.4 & 78.1 & 82.9 & 56.4 & 46.6 & 56.0 & 36.3 & 32.6 & 36.8 \\
\hline
\end{tabular}


Table 8. Measured, uncalibrated and calibrated energy balance.

\begin{tabular}{|l|c|c|c|}
\hline \multirow{2}{*}{ Consumption } & \multicolumn{3}{c|}{ Energy, $\mathrm{kWh} / \mathrm{m}^{2}$} \\
\cline { 2 - 4 } & Measured & Uncalibrated & Calibrated \\
\hline Space Heating (SH) & 78.24 & 83.36 & 78.06 \\
\hline Domestic Hot Water (DHW) & 29.92 & 35 & 29.48 \\
\hline DHW circulation heat loss & 26.50 & 11.56 & 26.49 \\
\hline Fans and pumps & \multirow{3}{*}{36.34} & 3.57 & 4.41 \\
\cline { 1 - 2 } \cline { 4 - 4 } Appliances & & 22.03 & 24.23 \\
\hline Lighting & $\mathbf{1 7 1 . 0}$ & $\mathbf{1 6 2 . 5}$ & $\mathbf{1 7 0 . 4}$ \\
\hline Total
\end{tabular}

The index of agreement and CV(RMSE) methods were used to evaluate the simulation model accuracy, as described in section 2.2. Table 9 shows $\mathrm{d}$ and $\mathrm{CV}(\mathrm{RMSE})$ values in three energy demand categories (SH, DHW and total electricity).

Table 9. The $\mathrm{d}$ and CV(RMSE) values after model calibration.

\begin{tabular}{lcc}
\hline \multicolumn{1}{c}{ Energy demand } & Index of agreement, d & CV(RMSE) \\
\hline SH & 0.99 & $8.90 \%$ \\
DHW & 0.78 & $3.10 \%$ \\
Total Elec. & 0.72 & $5.70 \%$ \\
\hline
\end{tabular}

\subsection{Measured and simulated indoor air temperature}

Measured indoor temperature duration curves in 5 apartments and simulated normal and coldest apartment results are shown in Figure 6 . Nearly $32 \%$ of the year, measured indoor temperature duration hours in apartment 1,2 and 5 were below $21^{\circ} \mathrm{C}$, and in apartment 3 and 4 , this was about $15 \%$. The black and red dashed lines show the simulated indoor air temperature duration curves in a normal and coldest apartment, respectively, while the air temperature setpoint is $21^{\circ} \mathrm{C}$. Moreover, the monthly average measured and simulated indoor air temperature duration curves are shown in figure 7.

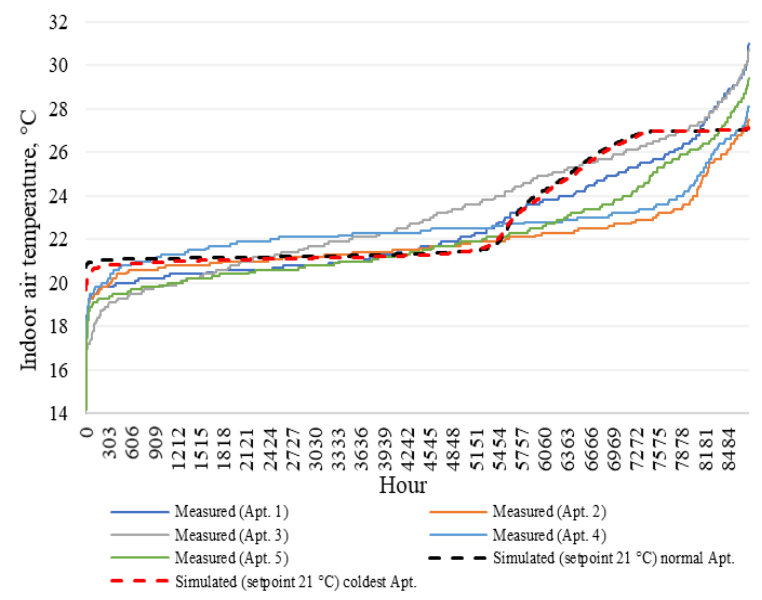

Figure. 6. Measured and simulated indoor air temperature duration curves in specific apartments.

The $70 / 40{ }^{\circ} \mathrm{C} \mathrm{HC}$ and air temperature setpoint of 21 ${ }^{\circ} \mathrm{C}$ maintained the mean air and operative temperatures in the EN 16798-1:2019 Category II range; nevertheless, there are few apartments where the indoor and operative temperature stay below $21^{\circ} \mathrm{C}$ and $20^{\circ} \mathrm{C}$, respectively.

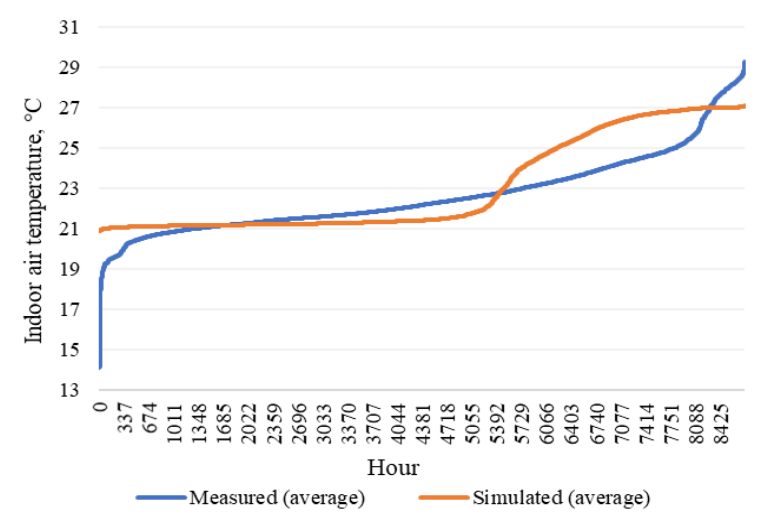

(a)

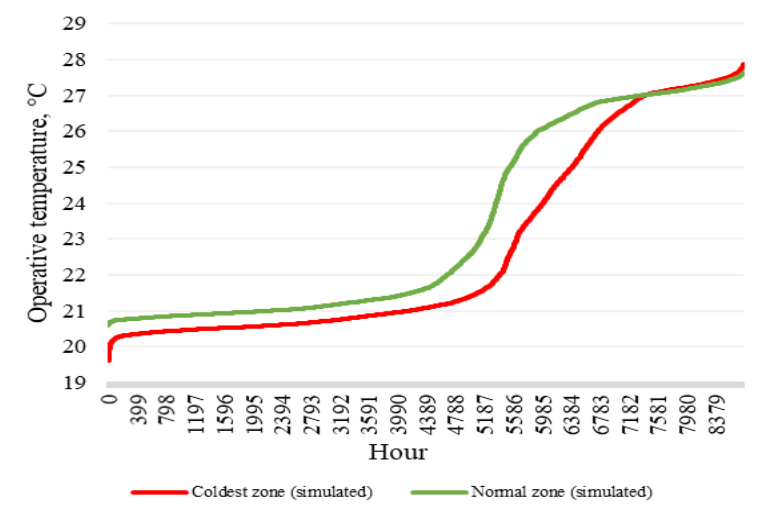

(b)

Figure 7. Simulated duration curve comparison, a) measured and simulated average indoor air temp. b) simulated operative temp. between the coldest apartment and a normal apartment.

The simulated mean air temperature was below 21 ${ }^{\circ} \mathrm{C}$ during $2.71 \%$ of yearly hours. Based on CEN/TR16798-2 2019, table B.2 [26], the indoor operative temperature's recommended design value in winter in Category II is $20^{\circ} \mathrm{C}$. In the simulation model, the operative temperature was below $20{ }^{\circ} \mathrm{C}$ during $0.04 \%$ of yearly hours, which stayed below the deviation criteria of $3 \%$ or $6 \%$ of the standard.

In simulated results, an average of all apartments is well in the standard range for all hours. Still, in the measured data, the indoor temperature remains below 21 ${ }^{\circ} \mathrm{C}$ for a considerable amount of time (Fig. 7a). The simulated operative temperature duration curve in figure $7 \mathrm{~b}$ shows the amount of hours below $20^{\circ} \mathrm{C}$ is very limited.

\subsection{Energy savings and room temperatures at reduced heating curves}

To determine the effects of lowering HC supply and return temperature impacts on air and operative temperatures and $\mathrm{SH}$ energy, the model was run with different heating curves. Original $70 / 40{ }^{\circ} \mathrm{C} \mathrm{HC}$ was changed to lower $\mathrm{HC}$ of $61 / 31^{\circ} \mathrm{C}$ and $65 / 35^{\circ} \mathrm{C}$, and the indoor air temperature setpoint was kept unchanged (21 $\left.{ }^{\circ} \mathrm{C}\right)$.

Undoubtedly, by reducing the supply and return temperature, the heat output of radiators will decrease. As a result, less SH energy is needed to heat the zones, but the temperature setpoint might not be achieved. 
Results of reduced HCs are shown in table 10. The mean air temperature and SH energy differences were higher in colder months due to the higher heating energy demand; however, the annual SH energy difference did not change considerably.

The amount of energy-saving potential of two HCs of $61 / 31{ }^{\circ} \mathrm{C}$ and $65 / 35{ }^{\circ} \mathrm{C}$ compared to $70 / 40{ }^{\circ} \mathrm{C}$ are shown in table 10 . Considering $\mathrm{HC} 65 / 35{ }^{\circ} \mathrm{C}$, the amount of energy-saving potential was calculated as 0.6 $\mathrm{kWh} / \mathrm{m}^{2} \mathrm{a}$, which is $0.8 \%$ of $\mathrm{SH}$ energy. However, this insignificant

Table 10. Mean air temperature and $\mathrm{SH}$ energy comparison at reduces $\mathrm{HCs}$.

\begin{tabular}{|l|c|c|c|c|c|c|}
\hline \multirow{3}{*}{ Month } & \multicolumn{3}{|c|}{ Mean air temp., ${ }^{\circ} \mathrm{C}$} & \multicolumn{3}{c|}{ SH energy, $\mathrm{kWh} / \mathrm{m}^{2}$} \\
\cline { 2 - 7 } & $\begin{array}{c}\mathrm{HC} 61 / 31 \\
{ }^{\circ} \mathrm{C}\end{array}$ & $\begin{array}{c}\mathrm{HC} 65 / 35 \\
{ }^{\circ} \mathrm{C}\end{array}$ & $\begin{array}{c}\mathrm{HC} 70 / 40 \\
{ }^{\circ} \mathrm{C}\end{array}$ & $\begin{array}{c}\mathrm{HC} 61 / 31 \\
{ }^{\circ} \mathrm{C}\end{array}$ & $\begin{array}{c}\mathrm{HC} 65 / 35 \\
{ }^{\circ} \mathrm{C}\end{array}$ & $\begin{array}{c}\mathrm{HC} 70 / 40 \\
{ }^{\circ} \mathrm{C}\end{array}$ \\
\hline Jan. & 20.97 & 21.08 & 21.17 & 13.12 & 13.22 & 13.30 \\
\hline Feb. & 20.97 & 21.08 & 21.17 & 14.72 & 14.80 & 14.87 \\
\hline Mar. & 21.01 & 21.11 & 21.2 & 13.82 & 13.92 & 14.00 \\
\hline Apr. & 21.29 & 21.36 & 21.42 & 6.65 & 6.71 & 6.76 \\
\hline May & 25 & 25.01 & 25.03 & 0.91 & 0.92 & 0.93 \\
\hline Jun. & 25.83 & 25.83 & 25.83 & 0.00 & 0.00 & 0.00 \\
\hline Jul. & 26.54 & 26.54 & 26.54 & 0.00 & 0.00 & 0.00 \\
\hline Aug. & 26.48 & 26.48 & 26.48 & 0.00 & 0.00 & 0.00 \\
\hline Sep. & 23.67 & 23.67 & 23.68 & 0.64 & 0.66 & 0.67 \\
\hline Oct. & 21.34 & 21.39 & 21.45 & 5.85 & 5.93 & 6.01 \\
\hline Nov. & 21.14 & 21.22 & 21.29 & 8.35 & 8.42 & 8.48 \\
\hline Dec. & 20.98 & 21.09 & 21.18 & 12.86 & 12.95 & 13.03 \\
\hline Total & - & - & - & $\mathbf{7 6 . 9}$ & $\mathbf{7 7 . 5}$ & $\mathbf{7 8 . 1}$ \\
\hline
\end{tabular}

energy-saving potential compromised thermal comfort because the annual percentage of mean air temperature below $21^{\circ} \mathrm{C}$ increased to $9.02 \%$, which is out of the deviation range of $6 \%$ of CEN/TR16798-2 2019.

The average mean and operative temperature length of deviation of yearly hours are shown in table 11 . Based on CEN/TR16798-2:2019 criteria of 3 and $6 \%$, the average operative temperature percentage below $20^{\circ} \mathrm{C}$ is well in the range with all HCs. However, the average mean air temperature percentage below $21^{\circ} \mathrm{C}$ with $\mathrm{HCs}$ $61 / 31^{\circ} \mathrm{C}$ and $65 / 35^{\circ} \mathrm{C}$ is not acceptable.

Table 11. The average mean air and operative temperature deviation of yearly hours and energy-saving potential with different heating curves.

\begin{tabular}{cccc}
\hline $\begin{array}{c}\text { Heating curve } \\
\text { combination, } \\
\left({ }^{\circ} \mathrm{C}\right)\end{array}$ & $\begin{array}{c}\text { Average annual } \\
\text { mean air temp. } \\
\text { below } 21^{\circ} \mathrm{C},(\%)\end{array}$ & $\begin{array}{c}\text { Average annual } \\
\text { operative air temp. } \\
\text { below } 20^{\circ} \mathrm{C},(\%)\end{array}$ & $\begin{array}{c}\text { Energy- } \\
\text { saving } \\
\text { potential, } \\
\mathrm{kWh} / \mathrm{m}^{2} \mathrm{a}\end{array}$ \\
\hline $61 / 31$ & 21.56 & 0.81 & 1.13 \\
$65 / 35$ & 9.02 & 0.16 & 0.53 \\
$70 / 40$ & 2.71 & 0.04 & - \\
\hline
\end{tabular}

The average indoor air temperature is illustrated in figure 8. The $\mathrm{HC} 61 / 31^{\circ} \mathrm{C}$ delivered the lowest average indoor air temperature monthly values yet above $21^{\circ} \mathrm{C}$ in all months. However, $21.56 \%$ of the average hourly values stayed below $21{ }^{\circ} \mathrm{C}$ (Table 10) for $\mathrm{HC} 61 / 31{ }^{\circ} \mathrm{C}$. Therefore, thermal comfort was compromised dramatically.

According to CEN/TR16798-2 2019, table E.1 [26], the yearly hours' deviation criterion can be selected as $3 \%$ or $6 \%$. The annual hours' deviation of air temperature percentage below $21{ }^{\circ} \mathrm{C}$ and the annual hours' deviation of operative temperature percentage below $20{ }^{\circ} \mathrm{C}$ in specific apartments at different heating curves are illustrated in figure 9.

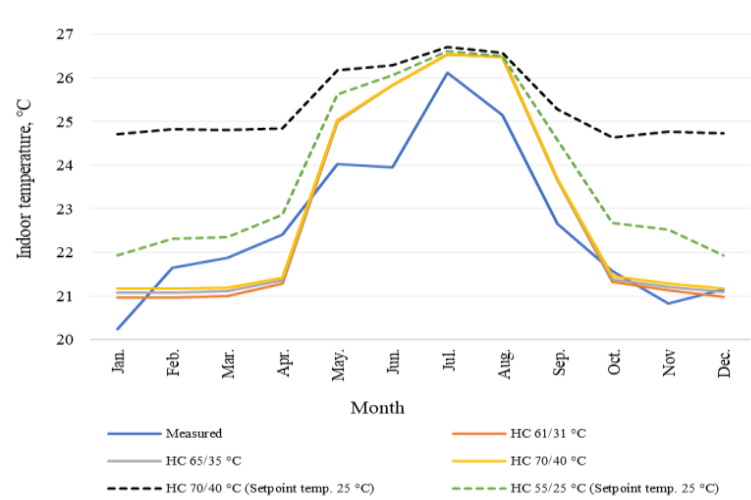

Figure 8. Comparison between the measured average indoor air temperatures and simulated HCs.

The annual hours' deviation of air temperature of $\mathrm{HC}$ $70 / 40{ }^{\circ} \mathrm{C}$ stays mostly below $5 \%$, whereas the lines representing $\mathrm{HC} 65 / 35{ }^{\circ} \mathrm{C}$ and $61 / 31{ }^{\circ} \mathrm{C}$ lie above the $5 \%$ line. In apartments A2.8 and B4.2, in nearly $45 \%$ of the annual hours, the air temperature is below $21{ }^{\circ} \mathrm{C}$ at HC $61 / 31^{\circ} \mathrm{C}$.

The percentage of annual hours deviation of air and operative temperature increases while the $\mathrm{HC}$ temperature decreases. The annual hours' deviation of operative temperature below $20{ }^{\circ} \mathrm{C}$ stays in the range except in apartment B3.2 and B4.2 at $\mathrm{HC} 61 / 31^{\circ} \mathrm{C}$.

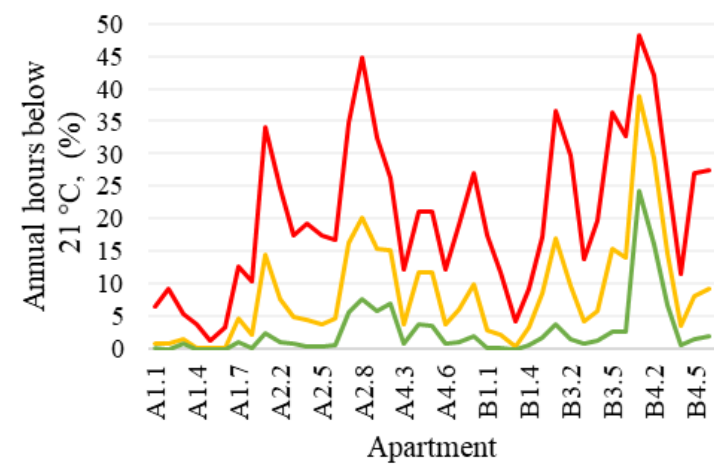

$\longrightarrow \mathrm{HC} 61 / 31{ }^{\circ} \mathrm{C}-\mathrm{HC} 65 / 35^{\circ} \mathrm{C}-\mathrm{HC} 70 / 40{ }^{\circ} \mathrm{C}$

(a)

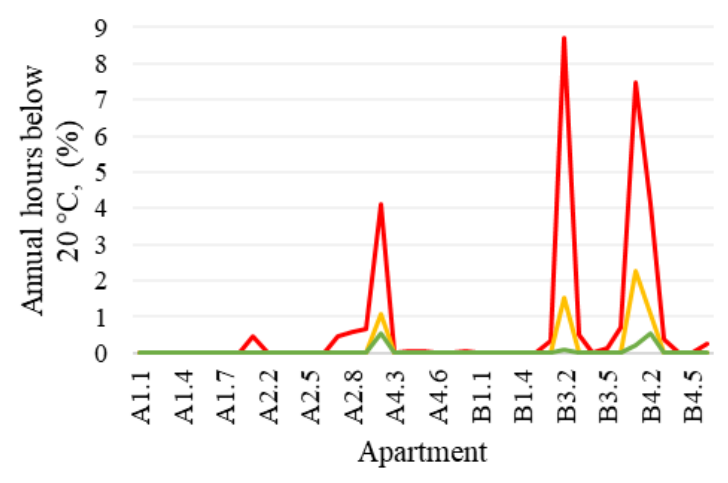

$\longrightarrow \mathrm{HC} 61 / 31{ }^{\circ} \mathrm{C}-\mathrm{HC} 65 / 35^{\circ} \mathrm{C}-\mathrm{HC} 70 / 40{ }^{\circ} \mathrm{C}$

(b)

Figure 9. The annual hours' deviation of a) mean air temperature percentage below $21^{\circ} \mathrm{C}$ b) operative temperature percentage below $20^{\circ} \mathrm{C}$. 


\subsection{Energy-saving potential in the case of fully open or broken thermostats}

As our previous analyses showed that it is impossible to save energy without compromising thermal comfort in the studied building, we simulated a hypothetical situation of an overheated building. For that purpose, we assumed that the thermostats are either fully open or broken, which was described with a setpoint temperature of $25{ }^{\circ} \mathrm{C}$. The corresponding monthly indoor air temperature is shown with dashed lines for two HCs in Figure 8.

Indoor air temperature duration curves of the coldest and warmest apartment are compared in Figure 10 for $\mathrm{HCs}$ of $70 / 40{ }^{\circ} \mathrm{C}$ and $55 / 25^{\circ} \mathrm{C}$. For $\mathrm{HC} 70 / 40{ }^{\circ} \mathrm{C}$, indoor air temperature stays below $21^{\circ} \mathrm{C}$ only $0.9 \%$ of the time, meaning that the building is overheated. Reducing the flow temperature to a lower heating curve of $55 / 25^{\circ} \mathrm{C}$ resulted in good energy saving, but $\mathrm{SH}$ energy of 82.9 is still higher than 78.1 with original $\mathrm{HC}$ of $70 / 40{ }^{\circ} \mathrm{C}$ and $21^{\circ} \mathrm{C}$ setpoint. The annual hours' deviation below $21^{\circ} \mathrm{C}$ air temperature with $\mathrm{HC} 70 / 40$ and $21^{\circ} \mathrm{C}$ setpoint is similar to $\mathrm{HC} 55 / 25^{\circ} \mathrm{C}$ and $25^{\circ} \mathrm{C}$ setpoint. Therefore, the central control with the heating curve only provided worse energy performance at the same thermal comfort level compared to normal control with thermostats which compensate great variation of heat losses and heat gains in different apartments.

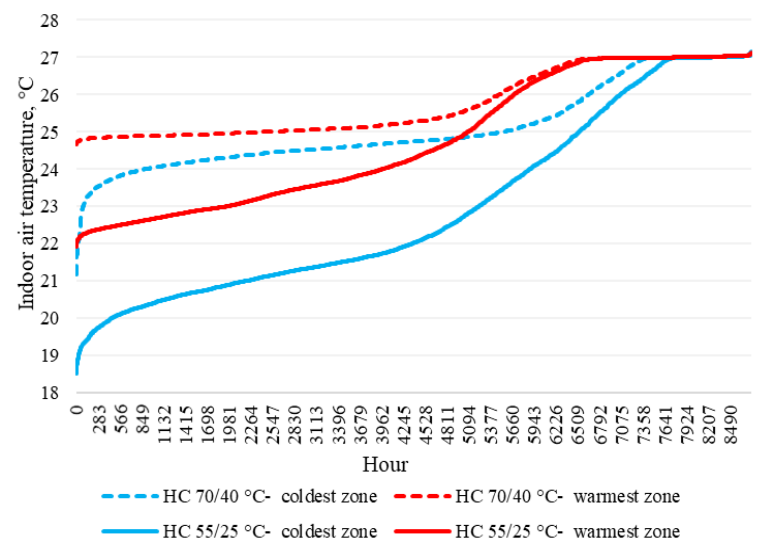

Figure 10: Simulated duration curve with setpoint $25^{\circ} \mathrm{C}$ comparison between $\mathrm{HC} 70 / 40{ }^{\circ} \mathrm{C}$ and $\mathrm{HC} 55 / 25^{\circ} \mathrm{C}$.

SH energy at fully open thermostats is compared with the original $70 / 40{ }^{\circ} \mathrm{C} \mathrm{HC}$ and $21{ }^{\circ} \mathrm{C}$ setpoint in Figure 11. The SH energy monthly values of $\mathrm{HC} 55 / 25$ ${ }^{\circ} \mathrm{C}$ and temperature setpoint $25^{\circ} \mathrm{C}$ are tabulated in table 7 , showing generally slightly elevated values but a good fit with measured data at warmer months. The temperature setpoint $21^{\circ} \mathrm{C}$ represents the thermostats' correct operation, and the temperature setpoint $25^{\circ} \mathrm{C}$ fully open thermostats. In the latter case, $\mathrm{HC}$ needs to be drop down to avoid strong overheating of the building. It is interesting to see that the shape of the measured indoor temperature graph in Figure 8 is more close to simulated $\mathrm{HC} 55 / 25^{\circ} \mathrm{C}$ with $25^{\circ} \mathrm{C}$ setpoint than the shape of $70 / 40{ }^{\circ} \mathrm{C} \quad \mathrm{HC}$ and $21{ }^{\circ} \mathrm{C}$ setpoint. Simultaneously, both indoor temperatures and $\mathrm{SH}$ energy of $\mathrm{HC} 55 / 25^{\circ} \mathrm{C}$ with $25^{\circ} \mathrm{C}$ setpoint are elevated, indicating that in reality, the situation might be that in some apartments, $21^{\circ} \mathrm{C}$ setpoint is maintained and in some apartments not.

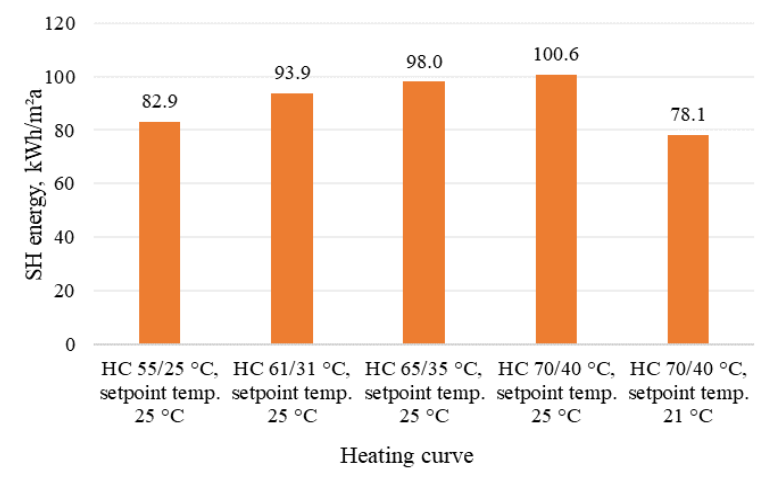

Figure 11: SH energy amount in different HC combinations while thermostats are fully open or broken (temp. setpoint 25 ${ }^{\circ} \mathrm{C}$ ) and function normally (temp. setpoint $21^{\circ} \mathrm{C}$ ) in $\mathrm{HC}$ $70 / 40{ }^{\circ} \mathrm{C}$ case.

\section{Conclusion}

In this study, a calibrated simulation model of an existing apartment building from 1981 was developed based on measured energy and indoor temperature data. The model was applied to determine circulation heat losses of DHW and to analyse the energy-saving potential of central control in cases with correctly operated room thermostats and with fully open or broken ones.

Uncalibrated simulation model showed higher space heating but lower DHW and electricity, resulting in the delivered energy difference of $11.42 \%$, which decreased to $0.73 \%$ after calibration. Subsequently, the model was calibrated against measured data with an accuracy of $8.9 \%$ calculated from monthly values.

Calculation of DHW consumption was possible from measured DH energy and determined DHW circulation heat loss. The average proportion of DHW to DCW was found $31.6 \%$ and was applied to calculate DHW usage in other months. DHW circulation heat loss revealed to be almost as high as DHW use and, therefore, important to consider in the energy balance. DHW circulation internal heat gain and ventilation airflow rate was determined with parametric simulations resulting in $85 \%$ and $0.291 / \mathrm{s} / \mathrm{m}^{2}$, respectively. Very high DHW circulation heat gain was explained by towel driers in bathrooms.

Standard $\mathrm{HC} 70 / 40{ }^{\circ} \mathrm{C}$ and air temperature setpoint of $21{ }^{\circ} \mathrm{C}$ maintained the mean air and operative temperatures well in the Category II range. Lowering the $\mathrm{HC}$ supply and return temperature to $65 / 35^{\circ} \mathrm{C} 21^{\circ} \mathrm{C}$ temperature setpoint provided a tiny amount of energysaving as $0.6 \mathrm{kWh} / \mathrm{m}^{2} \mathrm{a} \quad(0.8 \%$ of $\mathrm{SH}$ energy); nevertheless, it came on the cost of thermal comfort as the mean air temperature was below $21^{\circ} \mathrm{C}$ increased 
from $2.7 \%$ to $9.0 \%$ during yearly hours which is higher deviation than $6 \%$ recommended by the standard.

In the case of a hypothetical building with fully open or broken thermostats, $\mathrm{HC} 70 / 40{ }^{\circ} \mathrm{C}$ remarkably overheated the building. It was necessary to reduce the $\mathrm{HC}$ to $55 / 25{ }^{\circ} \mathrm{C}$ to achieve a similar indoor temperature deviation from $21{ }^{\circ} \mathrm{C}$. This very low heating curve indicates redistribution of heat from warmer rooms to colder but still provided higher SH of 82.9 vs 78.1 of original $\mathrm{HC}$ with $21{ }^{\circ} \mathrm{C}$ setpoint, showing the importance of proper operation of thermostats.

The results show that in the apartment building studied, there was no energy-saving potential at all. Even a small $5^{\circ} \mathrm{C}$ reduction in the $\mathrm{HC}$ resulting in a

\section{Reference}

[1] A. Costa, M.M. Keane, J.I. Torrens and E. Corry, "Building operation and energy performance:

Monitoring, analysis and optimisation toolkit," Applied energy, vol. 101, pp. 310-316, 2013.

[2] Eurostat, EU Commission, DG ENER, Unit A4, "Energy Statistics", 2017.

[3] EU Commission, "Energy Efficiency-Heating and Cooling", 2015.

[4] EU Energy in Figures Statistical Pocketbook, 2015.

[5] "EU 2030 climate \& energy framework", 2020.

[6] M. Tunzi, D.S. Østergaard, S. Svendsen, R.

Boukhanouf and E. Cooper, "Method to investigate and plan the application of low temperature district heating to existing hydraulic radiator systems in existing buildings," Energy (Oxford), vol. 113, pp. 413-421, Oct 2015.

[7] Connolly D.,Lund H.,Mathiesen B.V.,Werner S.,Möller B.,Persson U.,Boermans T., Trier D., Qstergaard P.A., Nielsen S., "Heat Roadmap Europe: Combining district heating with heat savings to decarbonise the EU energy system," Energy policy, 2014.

[8] Benakopoulos, Salenbien, Vanhoudt and Svendsen, "Improved Control of Radiator Heating Systems with Thermostatic Radiator Valves without Pre-Setting Function," Energies (Basel), vol. 12, no. 17, pp. 3215, Aug 2021.

[9] J. Gustafsson, J. Delsing and J. van Deventer, "Improved district heating substation efficiency with a new control strategy," Applied energy, vol. 87, no. 6, pp. 1996-2004, 2010.

[10] DS. Østergaard and S. Svendsen, "Experience from a practical test of low-temperature district heating for space heating in five Danish single-family houses from the 1930s," Energy (Oxford), vol. 159, pp. 569578, Sep 2015.

[11] M. Tunzi, D.S. Østergaard, S. Svendsen, R. Boukhanouf and E. Cooper, "Method to investigate and plan the application of low temperature district heating to existing hydraulic radiator systems in existing marginal $0.8 \% \quad \mathrm{SH}$ saving compromised thermal comfort. It can be seen that the average indoor temperature of the building is not a parameter allowing to estimate energy-saving potential. However, been elevated during a couple of months of the heating season, it was impossible to reduce $\mathrm{HC}$ due to the risk of too low temperatures in the coldest apartments.

This research was supported by the European Commission through the H2020 project Finest Twins (grant No. 856602). We are grateful to Pekka Takki from Helen Ltd for collaboration and sharing the energy data.

buildings," Energy (Oxford), vol. 113, pp. 413-421, Oct 2015.

[12] Klepeis N E, Nelson W C, Ott W R, et al., "The National Human Activity Pattern Survey (NHAPS): a resource for assessing exposure to environmental pollutants." J Expo Anal Environ Epidemiol, 2001. [13] A. Bruce-Konuah, R.V. Jones, A. Fuertes, L. Messi and A. Giretti, "The role of thermostatic radiator valves for the control of space heating in UK socialrented households," Energy and buildings, vol. 173, pp. 206-220, Aug 2015.

[14] Z. Liao, M. Swainson and A.L. Dexter, "On the control of heating systems in the UK," Building and environment, vol. 40, no. 3, pp. 343-351, 2005.

[15] B. Xu, A. Huang, L. Fu and H. Di, "Simulation and analysis on control effectiveness of TRVs in district heating systems," Energy and buildings, vol. 43, no. 5, pp. 1169-1174, 2011.

[16] "Autodesk Revit 2018," https://www.autodesk.com/products/revit/overview. [17] J. HENSEN and N. NAKAHARA, "Building simulation '99: Proceedings of the 6th International IBPSA Conference," Energy and buildings, vol. 3342001, 13-15 September 1999.

[18] K. Ahmed, P. Pylsy and J. Kurnitski, "Hourly consumption profiles of domestic hot water for different occupant groups in dwellings," Solar Energy, vol. 137, Nov 1, pp. 516-530, 2016.

[19] The national building code of Finland (Suomen säädöskokoelma), 2017.

[20] Guide - Calculation of building energy consumption and heating power demand 2012-2017

(Ohje - Rakennuksen energiankulutuksen ja lämmitystehontarpeen laskenta), 2017.

[21] K. Ahmed, P. Pylsy and J. Kurnitski, "Monthly domestic hot water profiles for energy calculation in Finnish apartment buildings," Energy and buildings, vol. 97, Jun 15, pp. 77-85, 2015.

[22] P. Krause, D.P. Boyle and F. Bäse, "Comparison of different efficiency criteria for hydrological model assessment," Advances in Geosciences, vol. 5, pp. 8997, 2005. 
[23] D.R. Legates and G.J. McCabe, "Evaluating the use of "goodness-of-fit" Measures in hydrologic and hydroclimatic model validation," Water Resources Research, vol. 35, no. 1, pp. 233-241, 1999.

[24] ASHRAE, "ASHRAE Guideline 14:

Measurement of Energy and Demand Savings", 2002.

[25] W. Tian, "A review of sensitivity analysis methods in building energy analysis," Renewable \& sustainable energy reviews, vol. 20, pp. 411-419, 2013.
[26] "Energy performance of buildings - Ventilation for buildings - Part 2: Interpretation of the requirements in EN 16798-1 - Indoor environmental input parameters for design and assessment of energy performance of buildings addressing indoor air quality, thermal environment, lighting and acoustics (Module M1-6)", 2019. 